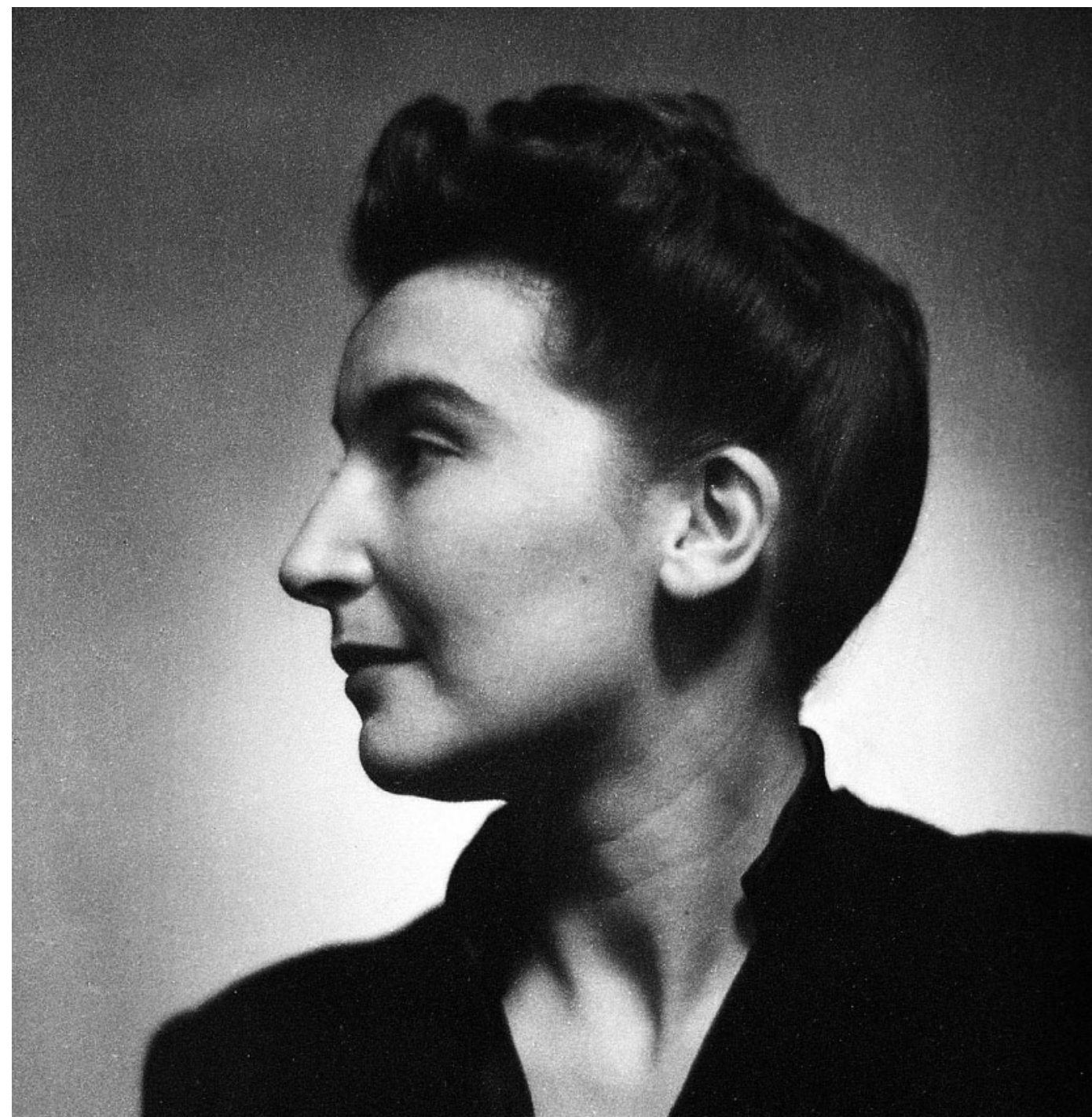

\title{
Sabe quem foi Manuela Porto?
}

\section{Diana Dionísio}

"Sabe quem foi Manuela Porto?" Algumas pessoas de 70 anos dirão que sim e contarão que dizia muito bem poemas; algumas pessoas de 50 anos dirão que já ouviram esse nome, mas afinal estão a confundi-lo com outro; as pessoas de 30 anos responderão simplesmente "não".

Manuela Porto, que dá hoje em dia nome a algumas ruas e pracetas e a uma sala do Teatro do Bairro Alto, não foi apenas uma pessoa como tantas outras - declamou os poetas do Novo cancioneiro em saraus culturais vigiados pela PIDE, colaborou nas revistas Vértice, Seara nova, Mundo literário e Eva e no jornal Diário de Lisboa, foi crítica de teatro, publicou livros de contos e uma novela, militou em movimentos políticos como o Movimento de Unidade Democrática, lutou pelos direitos e pela emancipação das mulheres, traduziu Anne Brontë, Katherine Mansfield, Virginia Woolf, Tchekov, foi actriz, recusou o teatro como era feito na sua altura e experimentou construir um outro teatro mas a memória colectiva não guarda tudo. Há que ter em conta que era uma mulher, há que ter em conta que viveu durante o fascismo, há que ter em conta que a sua vida foi curta e acabou de forma trágica. Suicidou-se com 42 anos.

Um erro repetido faz com que em várias notas biográficas acerca desta escritora, actriz e diseuse a sua data de nascimento seja 1912. Mas não. Manuela Porto nasceu em 24 de Abril de 1908, em Lisboa, cidade onde sempre viveu. Era filha de César Porto (1873-1944) jornalista, escritor, dramaturgo, ensaísta, tradutor e pedagogo, que se movia nos meios republicanos, maçónicos e anarquistas com Adolfo Lima, Araújo Pereira e tantos outros, que dirigiram, por exemplo, a Escola-Oficina n. ${ }^{\circ}$, no bairro da Graça. Foi essa escola que Manuela Porto frequentou, uma escola onde no início do século XX se tentou pôr em prática uma pedagogia diferente, "moderna", que tinha a preocupação de dar aos alunos uma formação multidisciplinar e onde se queria incentivar a autonomia e o espírito crítico.
Diana Dionisio

é Mestre em Estudos de Teatro pela Faculdade de Letras da Universidade de Lisboa, integra o dueto musical Pedro e Diana e é colaboradora da Casa da Achada Centro Mário Dionísio. 
cento e vinte e quatro

Sinais de cena 13.2010

Arquivo Solto

Diana Dionisio

Retrato de Manuel

Porto publicado na revista

Vértice em Julho de 1950

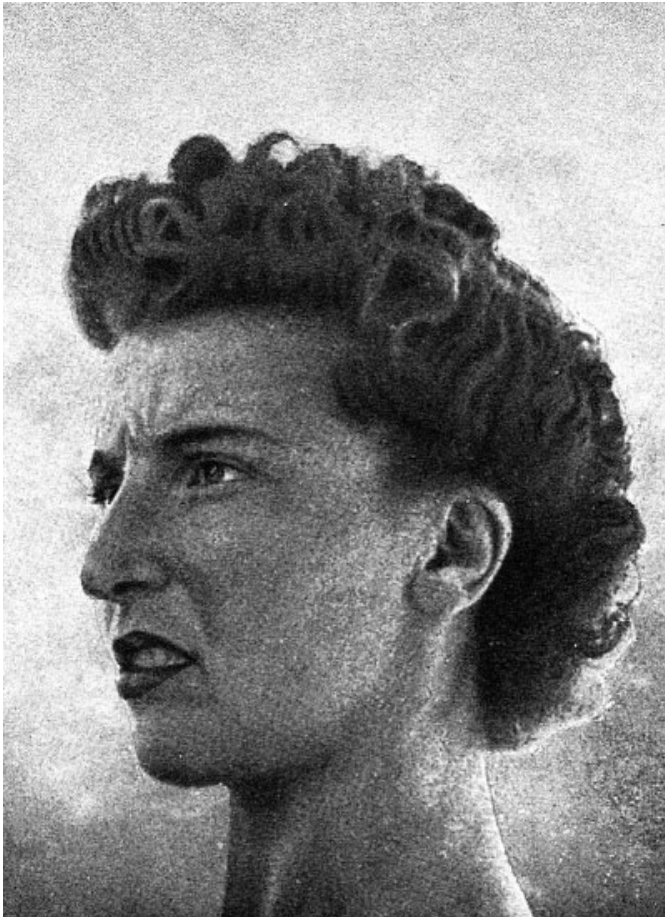

Em 1924, Manuela Porto frequentava a Escola-Teatro de Araújo Pereira (ligada à Escola Oficina n. ${ }^{\circ}$ 1) e, em Novembro, estreou-se como actriz no teatrinho Juvénia, na Rua das Escolas Gerais, na peça As irmãs, de Gustave Dévore. Dois anos depois, com dezoito anos, estreou-se profissionalmente na Companhia Rey Colaço-Robles Monteiro, na peça A petiza do gato, de Carlos Arniches. Em 1931 terminou o curso de teatro do Conservatório com 20 valores e prémio. Manuela Porto queria ser actriz.

Entusiasmada pelo teatro, entrou, entre a segunda metade dos anos vinte e o princípio dos anos trinta, em peças levadas à cena pela Escola-Teatro Araújo Pereira, pela Companhia Rey Colaço-Robles Monteiro, pela companhia de Gil Ferreira e pela Grande Companhia Dramática Portuguesa, contracenando com actores como Amélia Rey Colaço, Robles Monteiro, Gil Ferreira, Ilda Stichini, Alexandre de Azevedo, Alves da Cunha, Maria Matos, Joaquim de Oliveira, Assis Pacheco, Vasco Santana Berta de Bivar ou Constança Navarro. Pisou os palcos de vários teatros de Lisboa, como o Teatro Nacional, o Teatro do Ginásio e o Politeama, e representou ainda no Porto, em Coimbra e em Setúbal.

Mas a vida de actriz pouco durou. A desilusão com o meio teatral fê-la afastar-se dos palcos. Passou a dedicarse, para além de tantas outras actividades, à declamação de poesia, que era, nesta época, uma "moda" e era costume ser feita por actores, que aprendiam mesmo a fazê-lo nas aulas do Curso de Arte de Representar. Mas Manuela Porto não declamava "qualquer coisa".

Aliada à herança do património político e cultural que Manuela Porto recebeu do meio dos seus pais e ao seu casamento com outro artista (Roberto de Araújo, pintor e cenógrafo, filho de Araújo Pereira), foi a sua própria actividade artística e política que a fez relacionar-se ao longo da vida com personalidades como Avelino Cunhal, Maria Lamas, Francine Benoît, José Gomes Ferreira, José Régio, António de Navarro, João Gaspar Simões, Alberto de Serpa, Fernando Lopes-Graça, Flausino Torres, Manuel
Mendes, Adolfo Casais Monteiro, Manuel da Fonseca, Maria Keil, Maria da Graça Amado da Cunha, Mário Dionísio, João José Cochofel ou Carlos de Oliveira.

Descontentes com a situação política e cultural vigente, muitas destas pessoas integraram organizações e movimentos de oposição ao regime, e foi muitas vezes aí que Manuela Porto se encontrou com elas e com elas trabalhou. Mas foi também muito por via de certas actividades intelectuais e artísticas, organizadas por elas próprias, que estes laços da oposição e de uma "cultura de oposição" se fortaleceram. A ideia de pessoa como ser pensante e que deve cultivar-se intelectual e artisticamente era por si só uma ideia que os fazia oporem-se - e lutarem contra - a ditadura bolorenta, ignorante e silenciadora de Salazar. Assim, encontravam-se frequentemente em palestras, exposições, espectáculos, escreviam textos para revistas e jornais, trocavam livros entre si e foram muitas vezes os analistas críticos das produções artísticas uns dos outros e os organizadores de saraus em que eram as obras e as ideias uns dos outros que eram lidas ou discutidas.

Embora tenha recitado poetas do século XVIII, Manuela Porto foi sobretudo reconhecida por ser intérprete dos poetas da Presença e da geração seguinte, os poetas do Novo cancioneiro. Em saraus que contavam também com música, ou palestras introdutórias sobre o que seria ouvido, organizados por estes grupos de intelectuais empenhados em abrir espaço para divulgarem, entre si e para outros, as suas criações, disse poemas de Ângelo de Lima, Sá Carneiro, Fernando Pessoa, José Régio, António Navarro, Adolfo Casais Monteiro, Políbio Gomes dos Santos, Joaquim Namorado, Fernando Namora, João José Cochofel, Mário Dionísio, Álvaro Feijó, Carlos de Oliveira, António dos Santos Abranches, António Ramos de Almeida, Manuel da Fonseca, António Nobre, José Gomes Ferreira e Armindo Rodrigues. Foi ela que, pela primeira vez, recitou a Ode marítima de Álvaro de Campos, em 1938, após uma conferência na Casa das Beiras em que João Gaspar Simões falou sobre a obra do ainda desconhecido Fernando Pessoa, a génese dos seus 


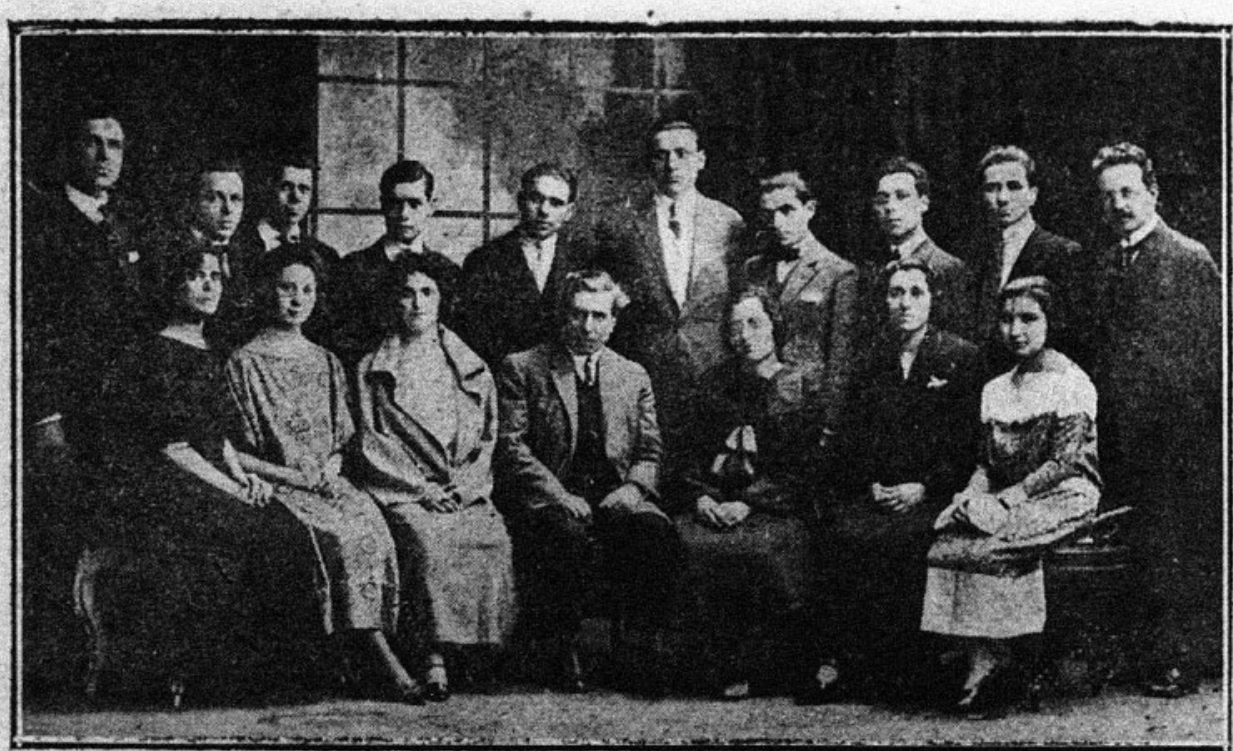

O_MESTRE E OS SEUS ALUMNOS

De pé, da esquerda para a direita : Srs. Antonio Vitorino, Cesar Viana, Luiz Boptista, Pedro Silpo, Antonio-Barreira, Corlos Silvo, Joťo Pedro de Andrade, Abilio Ribeiro, Hercalono Pereira, Cesar Porlo (protessor da Escola-Teatro Arajo Pereiro e adminutela, Emilia Joana, Manaela Porto

heterónimos e a importância da Ode marítima para a poesia moderna.

Sendo ela uma intelectual, uma pessoa das letras (e também escritora, vindo a publicar o seu primeiro livro de contos em $1945^{1}$ ), o exercício da declamação não era para ela tomado como um simples passatempo, mas sim como um trabalho sério, merecedor de um rigoroso estudo. Houve quem dissesse que levou sete meses a preparar a Ode marítima e na sua correspondência com Adolfo Casais Monteiro descobre-se a grande preocupação que tinha com a escolha dos textos e o seu alinhamento, quando preparava um recital. Também na sua maneira de dizer os poemas, segundo nos contam Luiz Francisco Rebello, Mário Dionísio ou José Régio (que a distinguiu de João Villaret numa carta ao actor ${ }^{2}$ ), transparecia o valor que dava a cada palavra e a cada poema e a seriedade com que encarava o que fazia.

Foram este extremo rigor e o enorme valor que dava ao trabalho artístico que não a deixaram manter-se no mundo dos teatros, embora tivesse sido esse o seu desejo primeiro. Nas suas criticas a espectáculos (que fez entre 1946 e 1950), lamentava permanentemente o estado do teatro em Portugal. Em 1948 escreveu uma novela sobre a vida de uma actriz que, tal como ela própria, se desiludiu com o teatro e a quem aconteceu tudo ao contrário daquilo com que sonhava - Uma ingénua: A história de Beatriz.

Nesta novela, conta-se a história de uma rapariga amante do teatro que, depois de sair do Conservatório, se aproxima do mundo cruel e miserável dos palcos e seus bastidores, o que the vale a degradação de toda a sua vida: desde a impossibilidade de brilhar como actriz e de prosseguir representando devido a uma velha empresária invejosa do seu êxito, ao casamento com um actor reputado que a deixa com um filho que acabará por morrer; desde uma relação de quase prostituição com um empresário rico que a leva para o seu teatro de revista, ao fim da sua curta vida em miséria absoluta, louca, na solidão do seu quarto alugado.
Apesar de Manuela Porto ter feito vários papéis de "ingénua" enquanto foi actriz e de alguns, como Gina Santos e Joaquim de Oliveira, verem pessoas reais nas personagens (a empresária seria Amélia Rey Colaço, a actriz Leonor d'Eça, e por ai em diante...), e embora o desencanto da autora com o teatro tenha sido igual ao de Beatriz, não é preciso vermos todos os passos desta novela como autobiográficos. Basta pensarmos que a autora se moveu, na "vida real", nas teias que passou para a ficção e analisarmos o texto, as personagens e os acontecimentos na vida da protagonista, para irmos ao encontro do seu pensamento e das críticas que fazia ao teatro como era feito no seu país. Não podemos deixar de pensar no Nacional de Amélia Rey Colaço quando a autora refere "aquela pocilga [que] era o teatro mais decente da capital! 0 único onde se representava uma ou outra peça séria e onde mantinham no reportório meia dúzia de obras consideradas clássicas".

Nos bastidores descritos por Manuela Porto, seja em teatros "decentes" ou em teatros de revista (para ela, "inferiores"), encontramos, entre pessoas que são mal pagas, terriveis ciúmes de uns actores por outros, cochichos e mentiras, relações de interesses e protecções, casos de verdadeira prostituição, numa individualista e selvagem sede de fama. E a autora mostra como estas relações que se jogam nos bastidores interferem no que é feito nos palcos. As decisões de encenação e de distribuição dos papéis, por exemplo, estão quase sempre dependentes dos caprichos daquele que tem mais poder e das intrigas de camarins. Os encenadores não estudam o texto - importam mais os figurinos e os cenários. Os gestos dos actores, a quem também não interessa o que estão a dizer, são sempre iguais, repetidos.

0 que Manuela Porto tenta dizer é claro. Aquele que tenha uma ideia diferente do que deva ser o teatro não se consegue integrar na grande máquina já instituida que continuamente trabalha. Os mais velhos e conservadores dominam os mais novos e de ideias frescas, num eterno
Araújo Pereira e os actores do Teatro Juvénia. Postal com a legenda: "0 mestre e os seus alunos. $\mathrm{Da}$ esquerda para a direita: $\mathrm{Sr}$ António Vitorino, César Viana, Luis Baptista, Pedro Silva, António Barreira, Carlos Silva, João Pedro de Andrade, Abilio Ribeiro, Herculano Pereira, César Porto (professor da EscolaTeatro Araújo Pereira e administrador do

"Juvénia"). Sentados: Sras. DD. Eugénia Silva, Libia de Almeida, Maria Silva, Araújo Pereira, Maria Manuela, Emilia Joana, Manuela Porto.".

1 Um filho mais e outras histórias, publicado pela editorial Inquérito.

Postumamente, em 1952 seria editado outro livro de contos: Doze histórias sem sentido.

2 "Manuela Porto - pelo menos quando a ouvi era, dizendo versos, um admirável exemplo de sensibilidade, inteligência atenção, finura. Todos os versos, todas as palavras se ouviam, - e com a sua expressão própria; ou, pelo menos, com a que lhe

atribuia a sua interpretação sempre inteligente. Vinham-nos as lágrimas aos olhos, ouvindo-a dizer certas coisas - e a gente nem dava por isso. Você, Villaret, criou uma maneira diversa: muito menos sóbria, muito menos atenta aos pormenores, isto é: aos valores de cada palavra e cada verso, muito menos analitica, digamos: e, em compensação, muito mais empolgante, muito mais sintética, muito mais apta a sugerir uma atmosfera, a dar o movimento primitivo da inspiração, a sublinhar as grandes linhas ondulatórias do poema" (Régio 1955). 


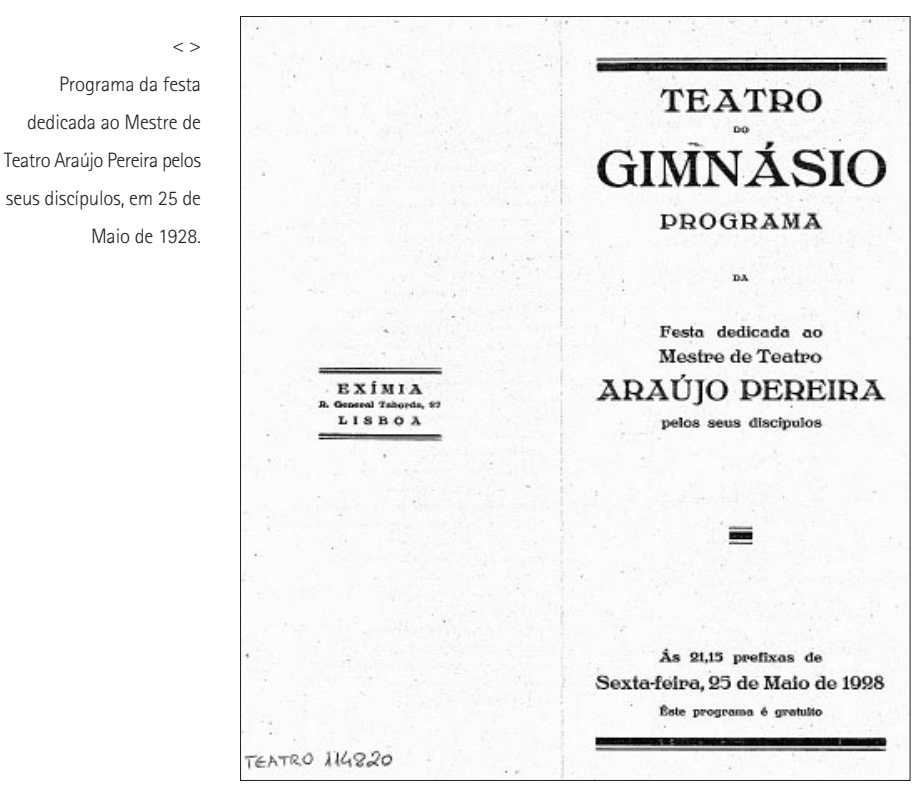

Programa do espectáculo Um Bragança, levado

cena pela Grande

Companhia Dramática Portuguesa, em 1931. Manuela Porto é a Infanta

D. Catarina.

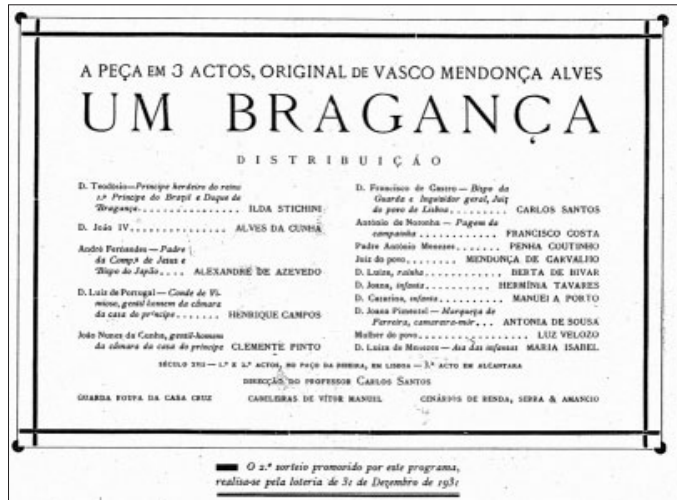

Programa do Serão de Arte pelo Corpo Cénico e o Coro

do Grupo Dramático

Lisbonense, na Academi de Amadores de Música, em 9 de Dezembro de círculo vicioso. Para a narradora, a culpa é de um todo, de uma engrenagem. Na sua Ingénua - para além do estado de miséria cultural e de valores de um país cabisbaixo e da situação da mulher que sabe ter de passar por severos obstáculos para ser economicamente autónoma -, Manuela Porto falou da situação do teatro em Portugal.

Mas não só numa ficção a escritora pensou e transmitiu as suas angústias relativamente ao estado pantanoso da arte teatral, angústias que partilhava com várias outras vozes da época que falavam repetidamente em "crise do teatro". Para além das críticas a espectáculos, escreveu ainda quatro reflexões sobre o assunto: "Comentários à margem do teatro" (Junho de 1946), "Considerações inúteis acerca de teatro" (Junho de 1947), "Algumas reflexões a propósito da crise de teatro" (Junho de 1949) e "Ainda e sempre a propósito de teatro" (Outubro de 1949).

Lendo esses artigos percebemos o que Manuela Porto achava que o teatro deveria ser: "Sempre foi característica e missão do teatro ser 'expressão-sintese' do sentimento íntimo e ideias, numa palavra, da 'fé' dos povos, só conseguindo atingir verdadeiro brilho e cumprir cabalmente a sua missão quando, transformada a palavra em acção, transborda o edifício teatral, alcança a rua, arrasta consigo a multidão, exprimindo, através dos meios à arte cénica peculiares, o mais importante da sensibilidade e do pensamento dessa massa de gente." (Porto 1949a: 341).
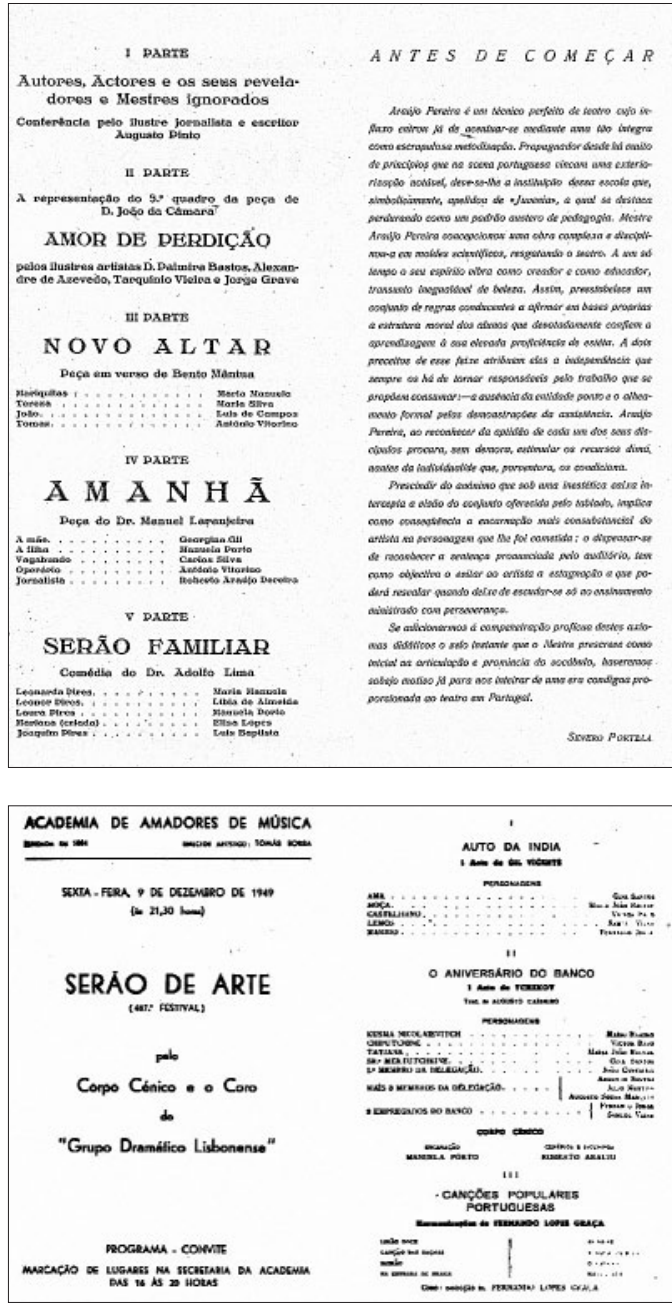

Para ela, teatro e vida são inseparáveis. 0 teatro deve falar da vida dos povos, deve "transbordar" para a rua, deve pôr questões às pessoas - aos espectadores e aos actores - que lhes digam de facto respeito, deve reflectir sobre a vida e o mundo e, consequentemente, agir sobre eles.

Há uma "palavra" que deve ser transformada em "acção". A essa palavra Manuela Porto dava toda a importância. 0 texto deveria ser, necessariamente, a base do espectáculo. Ir ver um espectáculo era, antes de mais, ir "escutar" uma obra de um autor e ir ver os actores a "encarnarem" as personagens de um texto. 0 dever de um espectáculo seria passar aquilo que o autor deixou no texto, um sentido profundo, uma"mensagem". 0

espectáculo deveria ser um intermediário entre as ideias do autor e o público.

A encenação e a interpretação têm, no pensamento de Manuela Porto, o dever de apreender a "mensagem" que está no texto para entregá-la aos espectadores. Ora, nas críticas que fez a espectáculos, é constante a ideia de que o virtuosismo exigido por certa grande obra dramática correspondeu a um "baixo nivel" de representação, não fazendo assim passar a ideia do autor e estar à altura da obra. Para além de se indignar várias vezes com as más traduções e com as imprecisas adaptações de textos, com o "corta e cola" de uma má dramaturgia, feita em nome da censura ou em nome do êxito comercial, considerava necessária uma boa interpretação da mesma: a 


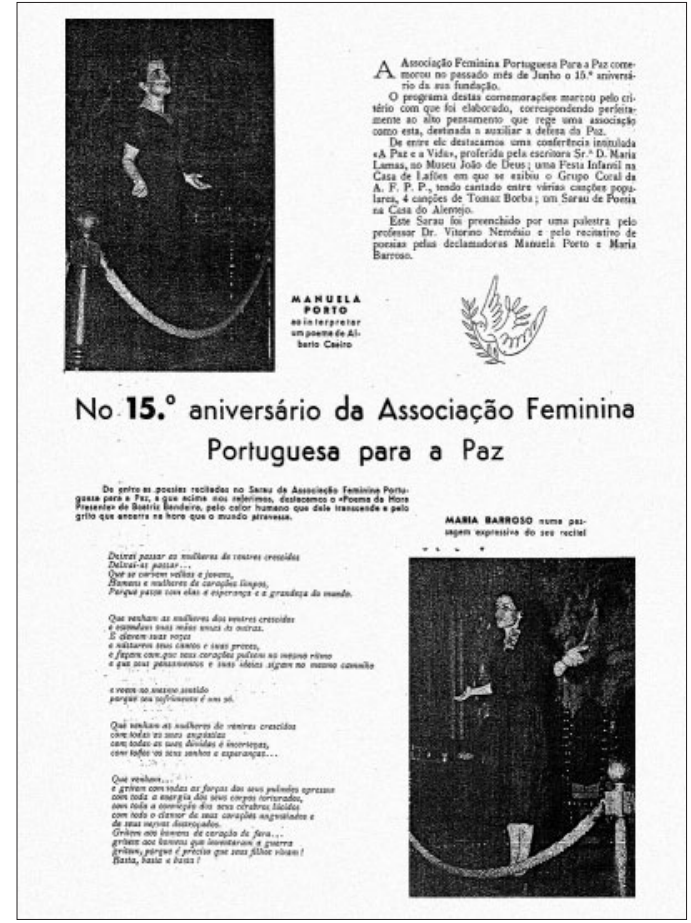

RECITAL DO NOVO CANCIONEIRO
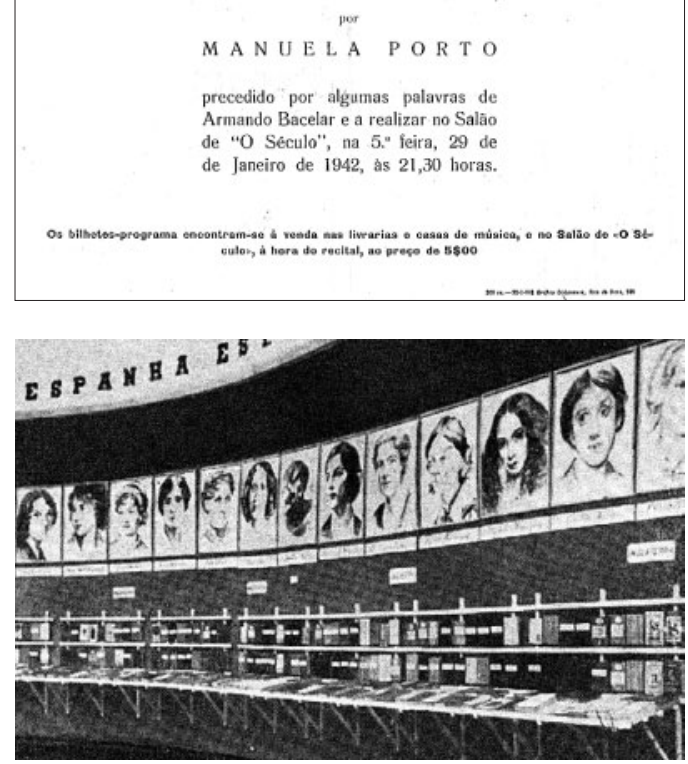

TEATRO-ESTÚDIO DO SALITRE

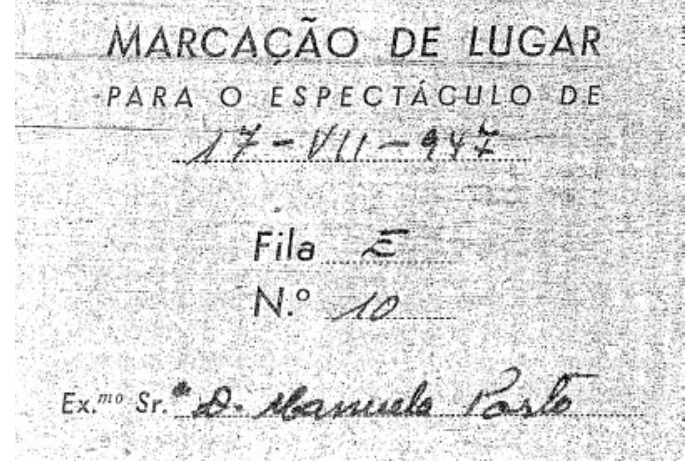

"interpretação geral", do encenador, e a interpretação do actor.

Em vários artigos, Manuela Porto acusava a "movimentação em momentos pouco oportunos", a "gesticulação que chega quase ao descritivo", o "tom uniforme" ou a "fatigante e laboriosa articulação" de perturbarem a compreensão do texto. Numa crítica a um espectáculo do Teatro-Estúdio do Salitre, reflecte sobre a incompatibilidade da forma de representação convencional em Portugal - um "'canon' estafado" - com as peças mais modernas, mais "arejadas". Para ela, o actor deveria saber focar a atenção dos espectadores no que é fulcral e deveria saber que tem nas suas mãos a condução desse foco. A técnica do actor deveria servir a passagem da mensagem do texto. Para o trabalho daquele, ela preferia as ideias de profundidade, essência, sintese e verdade - que implicariam ser fiel à palavra escrita - às ideias de superficialidade, aparência e fragmentação - que só poderiam conduzir à traição do texto. Eram também insistentemente dirigidas ao actor as ideias de trabalho e estudo.

Seria necessária coerência, a vários niveis, para que o espectáculo resultasse. Manuela Porto reclamava unidade harmonia, concordância, equilibrio de uns elementos em relação a outros, mas, sobretudo, de todos em relação ao texto. Opondo-se aos cenários e figurinos demasiado vistosos e a uma forma de representação descabida e exagerada, são frequentes no seu pensamento relativamente ao espectáculo teatral as ideias de clareza, simplicidade, despojamento, sobriedade, naturalidade, nitidez. Para tudo isso, seria necessária "inteligência".

Mas que era da inteligência? Para quem buscava essa inteligência, o teatro estava em crise. No artigo "Algumas reflexões a propósito da crise de teatro" enumerou quatro causas para ela: o desprezo relativamente ao "bom reportório clássico" (que se traduzia no escasso número de representações que o Teatro Nacional D. Maria II Ihes dedicava e ao elevado custo dos bilhetes, que não permitia que a elas assistissem nem as classes trabalhadoras nem
Noticia publicada no Jornal-Magazine da mulher sobre o recital de poesia de Manuela Porto comemorativo dos 15 anos da Associação Feminina Portuguesa para a Paz, na Casa do Alentejo, em Lisboa, em 9 de Junho de 1950.

Programa do Recital do Novo cancioneiro, no Salão do Século, em 29 de Janeiro de 1942

"Exposição de livros escritos por mulheres", organizada pelo Conselho Nacional de Mulheres Portuguesas, em Janeiro de 1947, na Sociedade Nacional de Belas Artes. Manuela Porto, então vicepresidente do CNMP, foi uma das principais organizadoras, tendo proferido uma conferência intitulada "Virginia Woolf: 0 problema da mulher nas letras".

Marcação de lugar para a sessão de 18 de Julho de 1947 do 5. espectáculo essencialista do TeatroEstúdio do Salitre de que Manuela Porto fez a 


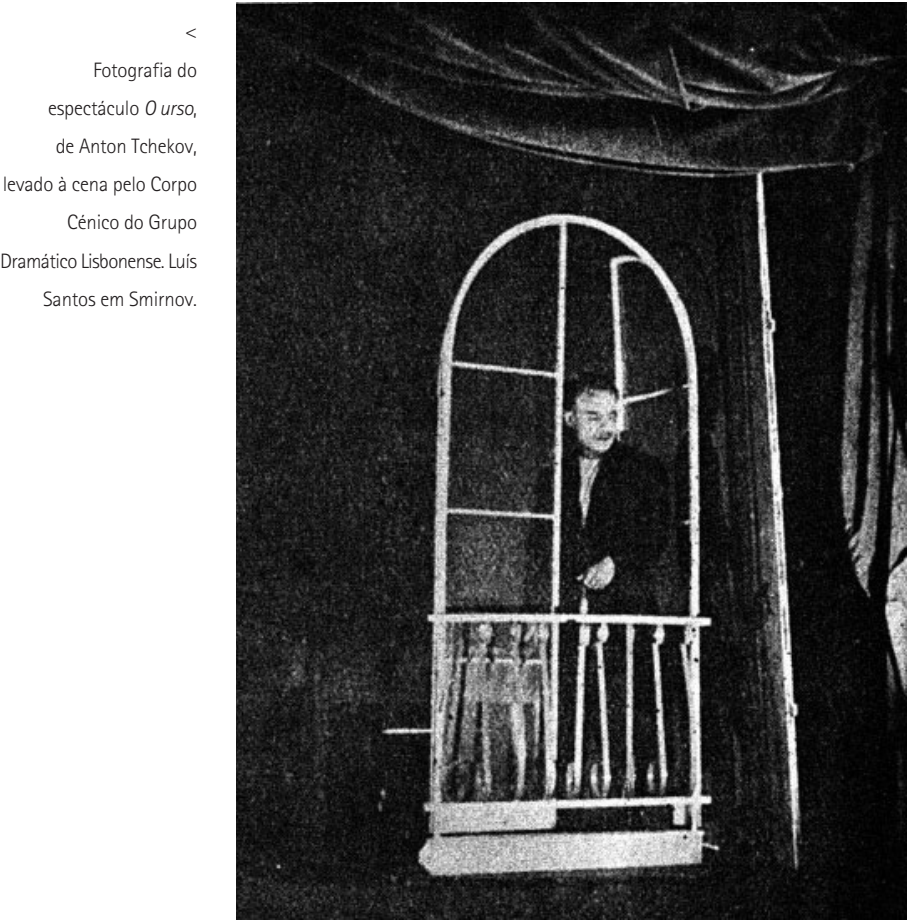

estudantes e nem mesmo a classe média), a falta de auxilio aos novos elementos e a dificuldade do seu acesso (que permitiria a renovação do teatro e um novo espírito do próprio reportório a apresentar), a nula protecção a grupos de teatro amadores e, por fim - mostrando mais uma vez o valor que dava à pedagogia e à formação -, a não multiplicação de cursos de dizer e representar e o ensino demasiado teórico e pouco prático dos cursos existentes.

Sobre o seu afastamento dos palcos, escreveu Manuela Porto: "[A] desistência, sem luta de maior, ao compreender que, no teatro português não havia encruzilhada sequer mas apenas um caminho existia, pouco interessante,

do Grupo Cénico e Cora

do Grupo Dramático Lisbonense, no Cine-Teatro de Vila Franca de Xira, em

10 de Junho de 1950 repleto de águas estagnadas e cardos sem beleza, por onde não me interessava realmente seguir" (Porto 1947)

Porém, o interesse que tinha pelo teatro impediu-a de se afastar completamente. Não aceitou a desistência. Para além de ter sempre continuado a escrever sobre teatro, esta actriz desiludida e preocupada com a situação do teatro criou em 1948 um grupo de teatro de amadores que dirigiu até à sua morte, em 1950: o Corpo Cénico do Grupo Dramático Lisbonense.

Em vários textos Manuela Porto apontou a criação de grupos amadores como uma solução para sair do ponto a que o teatro profissional chegara, para sair do "círculo vicioso" do teatro instituído. Neste seu grupo, Manuela Porto pôde pôr em prática muitas das ideias que tinha acerca de como deveria ser o teatro: desde a escolha de textos que considerava bons à utilização reduzida de cenários e figurinos, por exemplo.

0 Corpo Cénico do Grupo Dramático Lisbonense nasceu no seio do coro de jovens dirigido pelo maestro Fernando Lopes-Graça que se formou em 1945 no quadro do Movimento de Unidade Democrática. Este coro, composto maioritariamente por jovens do M.U.D., cantava canções populares bem como canções com letras dos poetas do Novo cancioneiro - que, editadas em 1946 em Marchas, danças e canções, foram rapidamente proibidas pela PIDE. Com a criação do grupo teatral orientado por

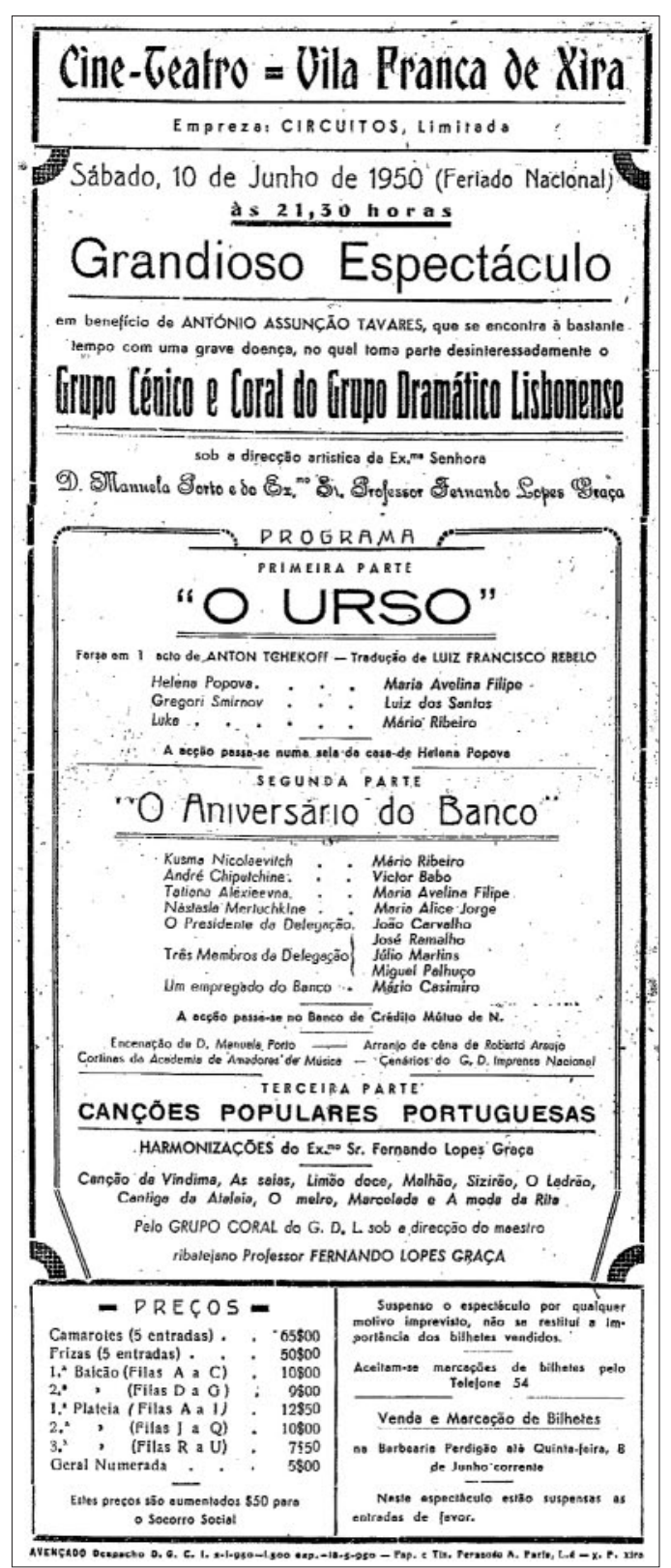

Manuela Porto, os espectáculos apresentados passaram a consistir em sessões mistas de teatro e música, normalmente apelidadas de "serões de arte".

0 que se construiu em pouco mais de um ano de vida deste grupo decerto não atingiu as aspirações de Manuela Porto e de Fernando Lopes-Graça quando tiveram a ideia de o criar: uma espécie de "'La Barraca' portuguesa", referindo-se ao grupo de teatro universitário ambulante fundado por Lorca em 1932 (Lopes-Graça 1952). Mas ainda fizeram - segundo o que é possivel hoje saber através dos poucos documentos existentes - mais de uma dezena de apresentações.

A encenação dos espectáculos era levada a cabo por Manuela Porto e os cenários e figurinos pelo seu marido, Roberto Araújo. As apresentações do grupo, com o coro, realizavam-se em sociedades de recreio e associações culturais, dentro e fora de Lisboa, e costumavam ser constituídas não por uma peça apenas, mas sim por duas, já que se tratava sempre de peças de um acto: 0 trágico à força, 0 urso e 0 aniversário do banco, de Tchekov, Entre a 

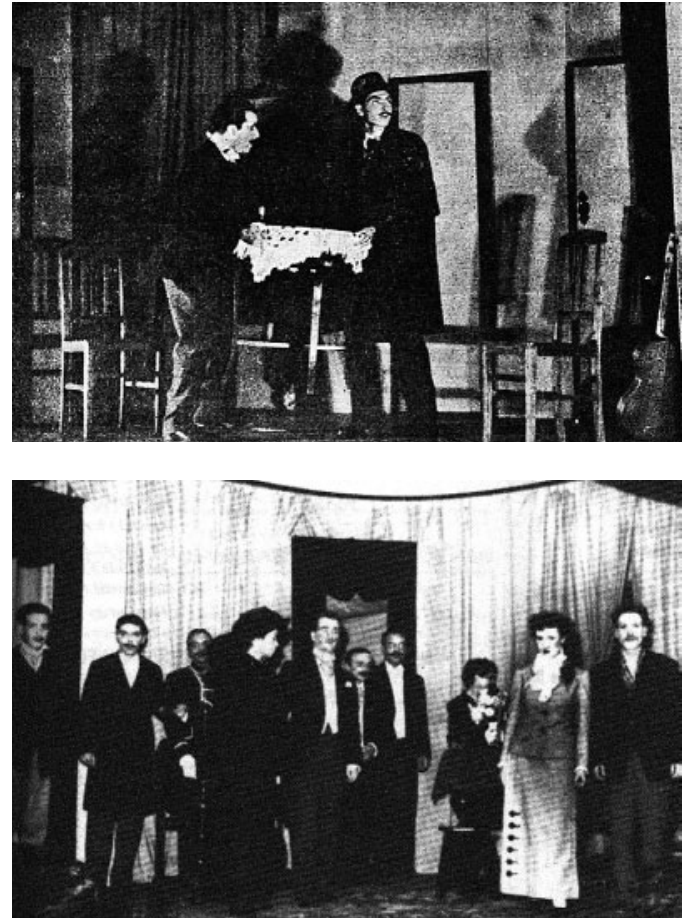

flauta e a viola, de Camilo Castelo Branco, Auto da Índia, de Gil Vicente, e Limões da Sicília, de Pirandello. Esta última numa tradução da própria Manuela Porto.

$\mathrm{Na}$ base da criação deste grupo, tal como se passava com o coro, e tal como nos anos 20 se passava com a Escola-Teatro de Araújo Pereira, havia uma ideia pedagógica, de educação popular. Araújo Pereira guiava-se pela ideia de "educação pela arte", Fernando Lopes-Graça fala-nos em "pôr a arte ao serviço do povo". Este serviço, aos olhos do maestro e da encenadora, que em muitos escritos 0 repetiram, não deveria ser feito "baixando a arte ao povo", mas sempre "elevando o povo através da arte", educando-o.

Para isso, Manuela Porto pedia da arte que falasse dos problemas que realmente podiam interessar os espectadores, dos novos problemas que thes eram postos na sua vida e no mundo e da procura de novos caminhos. Seria essa a forma de os "elevar": fazê-los pensar pelas suas próprias cabeças. Ela acreditava que os espectáculos de teatro poderiam transformar a humanidade.

0 reportório que escolheu para o corpo cénico do Grupo Dramático Lisbonense incluía os autores de "elevada categoria" que não via serem levados à cena no teatro instituido, ou que, quando via, julgava não serem bem interpretados. Gil Vicente é a este respeito o melhor exemplo. Antes de mais porque, sendo "popular", pertencia ao reportório clássico, podendo desta forma corresponder ao teatro de qualidade de que necessita o "povo" para se "elevar" e o público de teatro em geral para se "formar". Para além disso, porque a crítica social da sua obra mantinha a sua actualidade.

Em plena ditadura, em tempos de pobreza e analfabetismo, perante a prática regular da censura e submetido aos ditames comerciais, o teatro não estava a cumprir o seu papel de chegar à rua e levar luzes aos homens, era uma arma desperdiçada. Foi no teatro de amadores que Manuela Porto encontrou uma possibilidade de salvação. Do teatro e do povo. Em 1947, escreve numa crítica: "é indispensável que o teatro renasça,
Fotografia do espectáculo Entre a flauta e a viola, de Camilo Castelo Branco, levado à cena pelo Corpo Cénico do Grupo Dramático Lisbonense. Victor Babo em Gutierrez de Miramar e Armando Santos em José Pimenta.

pois um povo sem teatro é um povo por cuja vitalidade há tudo a recear" (Porto 1947b: 304). É impossivel não vermos aqui a ressonância de um manifesto de intelectuais portugueses, de apoio ao Movimento de Unidade Democrática, que a escritora assinara em 1945. Ai afirma-se: "Só um povo livre pode gerar uma cultura. Só a democracia permite a afirmação de um povo livre".

E hoje? Em que ponto estamos? 0 que mudou? Há pontos de fuga? Existe esse teatro que nos questiona e que desbrava caminhos para os nossos novos problemas? É ou não actual o pensamento de Manuela Porto?

\section{Referências bibliográficas}

AA.W. (1945), "0 momento eleitoral: um grupo de intelectuais portugueses dirige-se ao pais, afirmando que 'só um povo livre pode gerar uma cultura e só a Democracia permite a formação de um povo livre'", República, 10 de Novembro, pp. 4-5.

CAMILO, Viriato (1990), Fernando Lopes Graça e o Coro da Academia de Amadores de Música, Lisboa:, Seara Nova.

DIONisıo, Mário (1950), "Num mundo enorme e vazion, Vértice, vol. X, n. 86 , Outubro, pp. 198-205.

-- (1963), "Dizer poesia", Diário de Lisboa - Suplemento literário, 14 de Fevereiro, pp. 1 e 19.

G. V. [Guedes Vaz] (1925), "Escola-Teatro Araújo Pereira", De Teatro, n. 31, Abril, pp. 13-15.

LOPES-GRAÇA, Fernando (1949), "Valor estético, pedagógico e patriótico da canção popular portuguesa: Palestra realizada na Academia de Amadores de Música, para a apresentação do Coro do Grupo Dramático Lisbonense", Vértice, vol. VII, n. ${ }^{\circ} 69$, pp. 268-278.

-- (1952), "Recordando Manuela Porto", Comércio do Porto, 7 de Julho. MARQUES, Diana Dionisio Monteiro (2007), Um teatro com sentido: A voz crítica de Manuela Porto, dissertação de Mestrado em Estudos de

Teatro, apresentada à Faculdade de Letras da Universidade de Lisboa. PORTO, Manuela (1946), "Comentários à margem do teatro", Mundo literário: Semanário de crítica e informação literária, científica e artistica, n. 7, 22 de Junho, pp. 13, 16.

-- (1947), "Considerações inúteis acerca de teatro (A época de 46-47 terminou)", Vértice, vol. IV, n. 47 , Junho, pp. 164-166.

-- (1948), Uma ingénua: A história de Beatriz, Lisboa, Seara Nova.

-- (1949a). "Algumas reflexões a propósito da crise de teatro", Vértice, vol. VII, n. ${ }^{70}$, Junho, pp. 341-344.

-- (1949b), "Ainda e sempre a propósito de teatro", Vértice, vol. VIII, n. 74 , Outubro, pp. 217-220.

REBELLO, Luiz Francisco (1920), "Manuela Porto e o teatro", Vértice, vol. X, n. ${ }^{86}$, Outubro, pp. 192-194.

-- (1951), "Manuela Porto e o teatro" Jornal de Sintra, 7 de Janeiro. RÉGIO, José (1955), "Carta a João Villaret", Diário popular, 25 de Fevereiro. Dramático Lisbonense. Publicada em CAMILO (1990) com a legenda: "Interessante documento onde se reconhece

Manuela Porto ao fundo, aprestando-se para vir à boca de cena, e, ao centro, Gina Santos, que veio a abraçar a carreira profissional. Os restantes intervenientes eram, na maioria, elementos do Coro".
Espectáculo do Grupo 